\title{
Assessment of forest soil contamination in Krakow surroundings in relation to the type of stand
}

\author{
Ewa Błońska $^{1}$ - Jarosław Lasota ${ }^{1}$ Marcin Szuszkiewicz $^{2}$ - Adam Lukasik ${ }^{2}$. \\ Anna Klamerus-Iwan ${ }^{3}$
}

Received: 28 April 2016/ Accepted: 18 August 2016/Published online: 25 August 2016

(c) The Author(s) 2016. This article is published with open access at Springerlink.com

\begin{abstract}
The aim of the study was to determine the degree of soil pollution in different forest types around Krakow, using biochemical, chemical and magnetic methods. In assessing the degree of soil contamination, the impact of the forest species composition by comparing the surfaces of broadleaf and coniferous forest stands was taken into account. Enzymatic activity was related to other measures of pollution, i.e., heavy metal concentration, content of polycyclic aromatic hydrocarbons and level of magnetic susceptibility. The study was conducted in southern Poland. Krakow was the central point around which the test surfaces were designated. In soil samples $\mathrm{pH}$, soil texture and organic carbon, nitrogen, base cation contents, dehydrogenase and urease activities were determined. Additionally, heavy metal concentration, polycyclic aromatic hydrocarbons (PAHs) content and magnetic susceptibility were recorded. The obtained results confirm the high diversity of forest soil pollution around Krakow agglomeration. Significant differences in both the content of heavy metals, polycyclic aromatic hydrocarbons and values of the magnetic susceptibility were observed in the soils of forest complexes located in different directions away from Krakow and at various distances from Krakow. The level of contamination is related to the historical and
\end{abstract}

Ewa Błońska

eblonska@ar.krakow.pl

1 Department of Forest Soil Science, University of Agriculture, Al. 29 Listopada 46, 31-425 Kraków, Poland

2 Institute of Environmental Engineering, Polish Academy of Sciences, 34 M. Skłodowskiej-Curie St., 41-819 Zabrze, Poland

3 Department of Forest Engineering, University of Agriculture in Kraków, Al. 29 Listopada 46, 31-425 Kraków, Poland current deposition of industrial and urban dusts from Krakow and Silesia. The type of stand had a considerable influence on the content of polycyclic aromatic hydrocarbons. A higher content of aromatic hydrocarbons was observed in the soils of deciduous stands. A high level of magnetic susceptibility was observed in the soils of coniferous stands. The differences in enzymatic activity between the research plots result from different contents of PAHs and different amount of soil organic matter resulting from the species composition.

Keywords Heavy metals · Polycyclic aromatic hydrocarbons · Enzyme activity · Magnetic susceptibility . Broadleaf and coniferous forest stand

\section{Introduction}

The increase in air pollution is currently one of the major problems of civilization. This problem also concerns Krakow and its surroundings. For several months a year, Krakow, the second largest city in Poland, and its surroundings suffer from ever-higher pollution levels. In Krakow, the pollution of air and soil is one of the highest in Europe. The main components of air pollution in Krakow include carbon dioxide, sulfur dioxide, nitrogen oxides, suspended dust and polycyclic aromatic hydrocarbons (PAHs). The geochemical and/or magnetic methods have been successfully applied by many researchers to assess the impact of air pollution on the environment (Chodak et al. 2013; Klamerus-Iwan et al. 2015; Szuszkiewicz et al. 2016). In assessing the degree of soils contamination, the content of heavy metals is most often used. The contamination of soil by heavy metals is a significant problem, which leads to a negative influence on soil characteristics 
and limitations of productive and environmental functions (Friedlová 2010). Polycyclic aromatic hydrocarbons (PAHs) have strong toxic, carcinogenic and mutagenic effects, thus posing a risk to both soil organisms and people, and therefore, recent studies devote more attention to them (Maliszewska-Kordybach et al. 2008; Srogi 2007). PAHs are emitted to the atmosphere mainly from anthropogenic sources (Kwon and Choi 2014). A large amount of PAHs emitted to the atmosphere accumulates in soil via dry and wet deposition (Srogi 2007). Soil is a geoindicator of long-term environmental pollution because PAHs are strongly associated with soil organic matter (Wang et al. 2013). The sorption process plays a key role in controlling transport of PAHs during leaching, as well as in transformation and bio-accumulation processes (Reeves et al. 2004). Magnetic susceptibility is an effective, easy, fast and inexpensive method which can be used as a heavy metal pollution detection tool (e.g., Heller et al. 1998; Petrovský et al. 2000; Chaparro et al. 2006; Magiera et al. 2007; Xia et al. 2014), in particular for areas with a strong fly ash deposition. Łukasik et al. (2016) used magnetic susceptibility to assess the state of pollution of the upper horizons of soil forest reserves of Polish lowlands and uplands. Topsoil horizons can be significantly affected by airborne supply of elements, in particular from anthropogenic sources. The majority of urban-industrial dusts contain anthropogenic iron oxides (i.e., magnetite, maghemite, hematite) which are formed during high-temperature technological and metal extraction processes as well as during combustion of solid fuels, and they are accompanied by heavy metals (Hulett et al. 1980). These anthropogenic iron minerals are called technogenic magnetic particles (TMPs) and are significantly different from the minerals formed by natural processes because of stoichiometry and crystallographic structure as well as morphology (Magiera et al. 2011).

Monitoring by means of the characteristics of microbiological and biochemical properties of soils is successfully used in assessing the degree of soil contamination (Friedlová 2010). Biochemical properties reflect the changes, and they are directly related to the amount and activity level of soils microflora (Błońska and Januszek 2013). Soil enzymatic activities are sensitive bio-indicators of any natural and anthropogenic disturbance (Kumar et al. 2013). The activity of soil enzymes is one of the approved parameters used for the quality evaluation of soil polluted with PAHs (Lipińska et al. 2014). Klamerus-Iwan et al. (2015) confirmed that oil contamination with PAHs modified the physical properties of forest soils (air porosity, water resistance of aggregates) and had a negative impact on enzyme activity in soil. According to Sardar et al. (2010), high concentration of heavy metals ( $\mathrm{Cd}$ and $\mathrm{Pb}$ ) changes soil microbial community structure and activities.
The soil enzymatic activities decreased significantly with the increasing contamination by heavy metals, especially dehydrogenase and urease activities (Chen et al. 2005).

Changes in the species composition of forest stands may lead to modifications in soil properties. Tree species affect $\mathrm{pH}$ and cation-exchange capacity (CEC) of soil (Mueller et al. 2012; Gałka et al. 2014; Gruba and Mulder 2015). Species composition of trees affects the quantity and quality of soil organic matter (SOM) (Augusto et al. 2002; Hobbie et al. 2007) on which the accumulation of heavy metals (Biernacka and Małuszyńska 2006) and PAHs (Komprdová et al. 2016) depends. Heavy metals bound on insoluble humic substances are relatively immobile (Borůvka and Drábek 2004).

The distance from the pollution source has a significant impact on the degree of soil pollution. Šmejkalová et al. (2003), Wang et al. (2007) observed a statistically significant correlation between soil properties and the distance from the source of contamination. The heavy metals are deposited into soil at various distances depending on wind velocity and direction (Agrawal et al. 2010; Ogunkunle and Fatoba 2014). PAHs are adsorbed onto fine particles $(<2.5 \mu \mathrm{m})$, which are deposited slowly and, owing to atmospheric conditions, may be transported over long distances (Srogi 2007). According to Larsen and Baker (2003) heavy molecular weight PAHs, typical products of motor vehicle exhausts are not transported far from their source.

Few papers about soil pollution around urban areas in relation to the forest stands composition have been written so far. The primary objective of the research was to determine the degree of soil pollution in different forest types around Krakow, using biochemical, chemical and magnetic methods. The impact of the forest species composition by comparing the surfaces of broadleaf and coniferous forest stands was taken into account in assessing the degree of soil contamination. In addition to assessing the degree of accumulation of pollutants, the position of the surveyed plots in relation to Krakow, the direction of prevailing winds and the distance from the pollution sources were included. An attempt was made to use enzymatic activity of soils in assessing their pollution. Enzymatic activity was related to other measures of pollution, i.e., heavy metal concentration, content of PAHs and level of magnetic susceptibility.

\section{Materials and methods}

\section{Study area}

The study was conducted in southern Poland. Krakow was the central point around which the test surfaces were 
designated (Fig. 1). In the forest complexes, arranged in four directions around Krakow 48 research plots were established. They included four directions of the world W, $\mathrm{E}, \mathrm{S}$ and $\mathrm{N}$ in the two distances 15 and $35 \mathrm{~km}$ from Krakow, three surfaces in the stands of broadleaf trees (80- to 90-year-old oak stands) and three surfaces in the stands of coniferous trees (80- to 90-year-old pine stands). The main sources of pollution in Krakow are the steel producer ArcelorMittal Poland Unit in Krakow, power station "Łęg" and Krakow pharmaceutical company. In addition, the pollution is increased by passenger planes (Balice airport) and road traffic (Krakow is situated on the route from Medyka to Zgorzelec) (Fig. 1). In addition, significant amounts of pollutants are transferred from the Upper
Silesian Industrial Region, mainly due to the dominance of western winds (Fig. 1). The test area was dominated by Cambisols and Luvisols (IUSS Working Group WRB 2006).

Soil samples for laboratory analysis were taken in September 2015. At all the research plots, samples for laboratory analysis were collected after the removal of litter horizon from the depth of $0-15 \mathrm{~cm}$ (A horizon). In all the cases, samples for the research were collected from four sub-stands of soil. On each of the 48 research plots, the cumulative samples were taken. For determination of enzymatic activity and PAHs content, fresh samples of natural moisture were sieved through a sieve $(\varnothing 2 \mathrm{~mm})$ and stored at $4{ }^{\circ} \mathrm{C}$ in the dark before analysis.

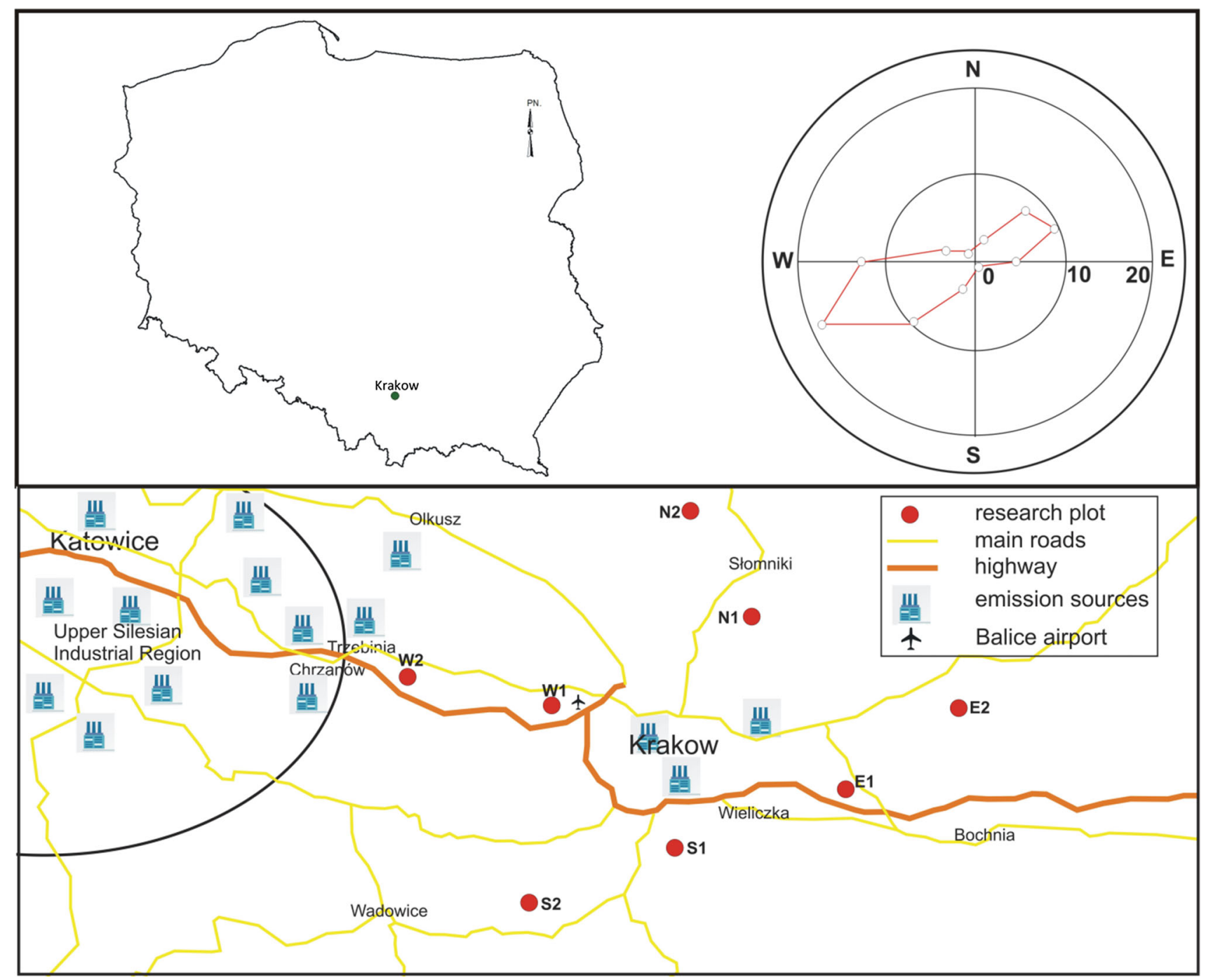

Fig. 1 Localization of study area (Krakow-southern Poland), distribution of research plots in Krakow surroundings, on each research plots the broadleaf and coniferous stands in three replications were chosen [S, W, N, E, the directions of the world; 1, 2, distance from Krakow (15 and $35 \mathrm{~km}$, respectively)] and wind direction in the area of study (Matuszko 2007) 


\section{Physicochemical analysis of soil}

Soil samples obtained in the field were dried and sieved through $2.0-\mathrm{mm}$ mesh. The $\mathrm{pH}$ of the samples was analyzed in $\mathrm{H}_{2} \mathrm{O}$ and $\mathrm{KCl}$ using the potentiometric method. The soil texture was determined by laser diffraction (Analysette 22, Fritsch, Idar-Oberstein, Germany). The content of carbon $(\mathrm{C})$ and nitrogen $(\mathrm{N})$ was measured with an elemental analyzer (LECO CNS TrueMac Analyzer (LECO, St. Joseph, MI, USA). As all the samples were carbonate-free, $\mathrm{C}$ was assumed to be organic carbon $(\mathrm{C}=$ Corg $)$. Base cations $\left(\mathrm{BC}=\mathrm{Ca}^{2+}, \mathrm{Mg}^{2+}, \mathrm{K}^{+}, \mathrm{Na}^{+}\right)$ concentrations were determined after extracting $10 \mathrm{~g}$ of soil with $100 \mathrm{~mL} 1 \mathrm{M} \mathrm{dm}^{-3}$ of a $\mathrm{NH}_{4} \mathrm{Cl}$ solution, followed by inductively coupled plasma-optical emission spectrometry (ICP-OES) (iCAP 6500 DUO, Thermo Fisher Scientific, Cambridge, UK). Total acidity (Ht) of soil was measured after extracting $5 \mathrm{~g}$ of soil with $30 \mathrm{~mL} 1 \mathrm{~mol}$ $\mathrm{L}^{-1}\left(\mathrm{CH}_{3} \mathrm{COO}\right)_{2} \mathrm{Ca}$ (shaking time $1 \mathrm{~h}$ ), followed by filtration. Soil on the filter was washed several times by extractant solution up to $200 \mathrm{~mL}$ (Buurman et al. 1996). Twenty-five milliliters of the obtained solution was titrated by potentiometric titration (automatic titrator Mettler Toledo) to $\mathrm{pH} 8.2$ with $0.1 \mathrm{~mol} \mathrm{~L}^{-1} \mathrm{NaOH}$. KCl-extractable $\mathrm{Al}$ (assumed to represent exchangeable $\mathrm{Al}$ ) was determined by extracting $40 \mathrm{~g}$ of soil with $100 \mathrm{~mL} \mathrm{KCl}$ for $1 \mathrm{~h}$, followed by filtration (Millipore $0.45 \mu \mathrm{m}$ ), using potentiometric titration of the supernant to $\mathrm{pH} 8.2$ (exchangeable acidity). The extracts, $25 \mathrm{~mL}$ subsamples were titrated potentiometrically to $\mathrm{pH} 8.2$ without and with the addition of $0.8 \mathrm{M} \mathrm{NaF}$. The results were used to calculate exchangeable acidity and exchangeable $\mathrm{H}^{+}$, respectively (Ostrowska et al. 1991). Al was calculated as the difference between exchangeable acidity and exchangeable $\mathrm{H}^{+}$. The content of $\mathrm{Cd}, \mathrm{Cr}, \mathrm{Cu}, \mathrm{Ni}, \mathrm{Pb}, \mathrm{Zn}$ was determined by the inductively coupled plasma-optical emission spectrometry (ICP-OES) (iCAP 6500 DUO, Thermo Fisher Scientific, Cambridge, UK) after prior mineralization in the mixture of concentrated nitric acid and perchloric at the ratio 2:1.

\section{Enzyme activity of soil}

Dehydrogenase activity (DH) was determined by the reduction of 2,3,5-triphenyltetrazolium chloride (TTC) to triphenyl formazan (TPF) using Lenhard's method according to the Casida procedure (Alef and Nannipieri 1995). Briefly, $6 \mathrm{~g}$ of soil was incubated with $1 \mathrm{~mL}$ of $3 \%$ TTC for $24 \mathrm{~h}$ at $37{ }^{\circ} \mathrm{C}$. TPF was extracted with ethyl alcohol and measured spectrophotometrically. Urease activity (UR) was determined according to Tabatabai and Bremner (1972) using a water-urea solution as a substrate. This activity was determined by the $\mathrm{NH}_{4}{ }^{+}$released after 2-h incubation at $37{ }^{\circ} \mathrm{C}$. The concentration of $\mathrm{NH}_{4}{ }^{+}$was measured at $410 \mathrm{~nm}$ by the colorimetric method (Alef and Nannipieri 1995).

\section{Measurements of magnetic susceptibility and frequency-dependent magnetic susceptibility}

The content and type of magnetic particles in study soil samples were determined on the basis of measurements of magnetic susceptibility. In prior magnetic analyses, the airdried soil samples were sieved through $2-\mathrm{mm}$ mesh and placed into diamagnetic plastic container $\left(10 \mathrm{~cm}^{3}\right)$. Lowfield magnetic susceptibility measurements were carried out using a MS2 Bartington laboratory magnetic susceptibility meter (Bartington Instruments Ltd.), equipped with a MS2B sensor (with coil capacity of $10 \mathrm{~cm}^{3}$ ) at low $(465 \mathrm{~Hz})$ and high $(4650 \mathrm{~Hz})$ frequency. The sensor was used to measure the volume of magnetic susceptibility $(\kappa)$, and the mass magnetic susceptibility $(\chi)$ was then calculated with respect to the mass of the sample and expressed in $\mathrm{m}^{3} \times \mathrm{kg}^{-1}$. The calculation of the $\chi$ value enabled comparing samples with different density values (from different genetic soil horizons). In addition, a percentage of frequency-dependent magnetic susceptibility $\left(\chi_{\mathrm{fd}} \%\right)$, was computed.

\section{Determination of polycyclic aromatic hydrocarbons}

Ten grams of soil were weighted from each sample, and then polycyclic aromatic hydrocarbons were extracted from these amounts with $70 \mathrm{~mL}$ of 2-propanol. The samples were centrifuged $(4500,5 \mathrm{~min})$, and the supernatant was collected. The supernatants were extracted to solid phase $\left(5 \mathrm{~mL} \mathrm{~min}^{-1}\right)$ - solid-phase extraction (Chromabond $\mathrm{Cn} / \mathrm{SiOH}$ ). The residue was dissolved in acetonitrile and analyzed with the HPLC method. The Dionex UltiMate 3000 HPLC system was equipped with a fluorescence detector (FLD) and Dionex UltiMate 3000 Column Compartment $-\mathrm{C} 185 \mu \mathrm{m}, 4.6 \times 100 \mathrm{~mm}$ HPLC column. The mobile phase was water (A) and acetonitrile (B) at a flow rate of $1 \mathrm{~mL} \mathrm{~min}{ }^{-1}$. From the standard PAH Calibration Mix (CRM 47940) at a concentration of $10 \mu \mathrm{g} \mathrm{mL}^{-1}$, the calibration solution at different concentrations (i.e., 0.1, $0.2,0.5,1,2 \mu \mathrm{g} \mathrm{mL}^{-1}$ ) was prepared. Each of the prepared solutions was dispensed to a chromatography columnobtained chromatograms designated the calibration curve. Then the soil samples in triplicate were dispensed. After each 9th analysis, the "unknown" sample (calibration solution with a concentration $0.1 \mu \mathrm{g} \mathrm{mL}^{-1}$ ) which was control material was injected. Twelve priority PAHs were determined: acenaphthylene (Acy), phenanthrene (Phe), fluoranthene (Flt), pyrene (Pyr), benzo(a)anthracene (BaA), chrysene $(\mathrm{Chr})$, benzo(k)fluoranthene $(\mathrm{BkF})$, benzo(b)fluoranthene $(\mathrm{BbF})$, benzo(a)pyrene $(\mathrm{BaP})$, indeno(1,2,3- 
c,d)pyren (IcdP), dibenzo(a,h)anthracene (DahA) and benzo(g,h,i)perylene (BghiP). The sum of PAHs was calculated (12 priority PAHs content was added). The sum of PAHs was calculated for soils in different localizations, under different forest stands. Diagnostic ratios have been used to distinguish the emission sources of PAHs, $\Sigma \mathrm{LMW} /$ $\Sigma$ HMW (Soclo et al. 2000), Flt/(Flt + Pyr) (Yunker et al. 2002), Flt/Pyr (Baumard et al. 1999) and IcdP/ (IcdP + BghiP) (Kwon and Choi 2014). The LMW/HMW ratio was calculated by the sum of low molecular weight PAHs with 3-4 rings and the sum of high molecular weight PAHs with 5-6 rings.

\section{Statistical analysis}

In order to reduce the number of variables in the statistical data set and to visualize the multivariate data set as a system of coordinates in a high-dimensional data space, the principal component analysis (PCA) method was applied. The PCA method was also used in order to interpret other factors, depending on the type of data set. In PCA, the chemical properties, enzymes activity of soil, magnetic susceptibility, the sum of PAHs, type of forest stands and characteristics description of the location (distance from Krakow and directions of the world) were used. Differences between the mean values were evaluated with the nonparametric Mann-Whitney $U$ and Kruskal-Wallis test. The statistical significance of the results was verified at the significance level of $\alpha=0.05$. All the statistical analyses were performed with Statistica 10 software (2010). The maps of the spatial distribution of $\chi$ value as well as contents of heavy metal and soil enzyme activities were generated using Surfer 8 program (Golden Software, LLC).

\section{Results}

\section{Physicochemical soil analysis}

Comparing soil of broadleaf and coniferous stands, no statistically significant differences in the content of sand, silt and clay were noted. Higher content of $\mathrm{C}$ was recorded in the soils of coniferous stand and base cations in the soil of broadleaf stand. Soil testing of broadleaf and coniferous stand did not differ statistically significantly in the content of carbon, nitrogen and base cations. Statistically significant differences between soils of coniferous and deciduous trees in $\mathrm{pH}$, acidity and $\mathrm{Al}$ content were observed (Table 1).

The test soils were characterized by differences in the content of heavy metals depending on the distance and direction of sampling in relation to Krakow (Fig. 2). Cadmium content was in the range of $0.49-3.22 \mathrm{mg} \mathrm{kg}^{-1}$. The highest cadmium content was recorded $35 \mathrm{~km}$ east of
Krakow in soils of both broadleaf and coniferous stands (Fig. 2). Copper content ranged from 4.16 to $48.08 \mathrm{mg} \mathrm{kg}^{-1}$. The lowest levels of copper have been reported north and south of Krakow, the highest $35 \mathrm{~km}$ west of Krakow, amounting to 48.08 and $46.81 \mathrm{mg} \mathrm{kg}^{-1}$ in deciduous and coniferous stands, respectively. The highest nickel contents have been noted $35 \mathrm{~km}$ east of Krakow in the soils of deciduous and coniferous stands ( 36.13 and $31.85 \mathrm{mg} \mathrm{kg}^{-1}$, respectively). At other locations, the nickel content ranged from 3.84 to $12.03 \mathrm{mg} \mathrm{kg}^{-1}$. In the examined soils, lead content ranged from 18.11 to $189.45 \mathrm{mg} \mathrm{kg}^{-1}$. The highest content was recorded in soils located $35 \mathrm{~km}$ west of Krakow $\left(189.45 \mathrm{mg} \mathrm{kg}^{-1}\right.$ in the soils of coniferous stands and $182.58 \mathrm{mg} \mathrm{kg}^{-1}$ in the soils of deciduous stands). Slightly lower lead contents were recorded in soils $15 \mathrm{~km}$ west of Krakow $\left(110.89 \mathrm{mg} \mathrm{kg}^{-1}\right.$ in the soils of coniferous stands and $80.20 \mathrm{mg} \mathrm{kg}^{-1}$ in the soils of deciduous stands). The highest zinc content was determined in soils $35 \mathrm{~km}$ east of Krakow; zinc content in the soils of coniferous stands amounted to $166.98 \mathrm{mg} \mathrm{kg}^{-1}$ and in the soils of deciduous stands to $182.41 \mathrm{mg} \mathrm{kg}^{-1}$. Statistically significant differences were noted in the content of heavy metals in relation to the location of research plots. Copper content in soils west of Krakow differed significantly compared with the soils to the south and north of Krakow $(H=12.688, p=0.0054)$. Lead content in soils west of Krakow was significantly different from the content in soils at other locations $(H=25.577$, $p=0.001)$. There were no statistically significant differences in the content of heavy metals between the soils of deciduous and coniferous stands (Table 1).

\section{Enzyme activity of soil}

The activity of the two studied enzymes varied depending on the species composition of the stand. Higher DH and UR activity was recorded in the soils of deciduous stands as compared to the soils of coniferous stands irrespective of the locations of sampling in relation to Krakow (Table 1; Fig. 3). In the soils of deciduous stands, the highest dehydrogenase activity was recorded $15 \mathrm{~km}$ west of Krakow and $35 \mathrm{~km}$ east of Krakow. In the soils of coniferous stands, the highest dehydrogenase activity was recorded $35 \mathrm{~km}$ north and south of Krakow (Fig. 3). Similarly to dehydrogenase activity, urease activity varied depending on the distance of the research area from Krakow. In the soils of deciduous stands, the highest urease activity was recorded $35 \mathrm{~km}$ to the east of Krakow. In the soils of coniferous stands, the highest urease activity was recorded $35 \mathrm{~km}$ north of Krakow.

In the case of the soils of deciduous stands, there is a relationship of enzymatic activity with the heavy metal content. Urease activity was positively correlated with the 
Table 1 Mean values, range and standard deviations (SD) of soil properties in group of coniferous and broadleaf forest stands

\begin{tabular}{|c|c|c|c|c|c|c|c|c|}
\hline & \multicolumn{4}{|c|}{ Coniferous stands } & \multicolumn{4}{|c|}{ Broadleaf stands } \\
\hline & Mean & Min & Max & SD & Mean & Min & Max & SD \\
\hline $\mathrm{pH} \mathrm{H}_{2} \mathrm{O}$ & $4.23^{\mathrm{a}}$ & 3.59 & 5.08 & 0.41 & $4.78^{\mathrm{b}}$ & 3.79 & 6.19 & 0.65 \\
\hline $\mathrm{pH} \mathrm{KCl}$ & $3.29^{\mathrm{a}}$ & 2.93 & 3.94 & 0.27 & $3.75^{\mathrm{b}}$ & 2.91 & 5.41 & 0.61 \\
\hline Sand & 49.59 & 22.65 & 92.45 & 22.45 & 46.59 & 11.55 & 88.50 & 22.30 \\
\hline Silt & 45.46 & 6.80 & 70.25 & 20.40 & 48.26 & 10.15 & 77.15 & 20.14 \\
\hline Clay & 4.51 & 0.60 & 9.60 & 2.44 & 5.15 & 1.25 & 11.70 & 2.70 \\
\hline $\mathrm{Ht}$ & $15.54^{\mathrm{a}}$ & 7.65 & 25.14 & 5.19 & $11.37^{\mathrm{b}}$ & 3.17 & 26.28 & 5.99 \\
\hline $\mathrm{Al}$ & $384.68^{\mathrm{a}}$ & 58.60 & 724.50 & 177.52 & $233.00^{\mathrm{b}}$ & 1.08 & 748.50 & 234.08 \\
\hline $\mathrm{N}$ & 0.40 & 0.16 & 0.76 & 0.16 & 0.37 & 0.11 & 0.81 & 0.17 \\
\hline $\mathrm{C}$ & 7.18 & 2.51 & 14.56 & 3.09 & 5.79 & 1.48 & 16.11 & 3.11 \\
\hline $\mathrm{C} / \mathrm{N}$ & 17.87 & 13.45 & 23.03 & 2.65 & 15.28 & 11.49 & 19.98 & 2.39 \\
\hline $\mathrm{Ca}$ & 3.62 & 0.78 & 10.81 & 3.16 & 5.78 & 0.96 & 21.71 & 6.46 \\
\hline $\mathrm{K}$ & 0.45 & 0.08 & 1.55 & 0.39 & 0.56 & 0.17 & 1.88 & 0.42 \\
\hline $\mathrm{Mg}$ & 0.60 & 0.09 & 1.89 & 0.54 & 1.02 & 0.21 & 4.37 & 1.29 \\
\hline $\mathrm{Na}$ & 0.04 & 0.01 & 0.10 & 0.02 & 0.04 & 0.00 & 0.20 & 0.05 \\
\hline $\mathrm{BC}$ & 4.72 & 1.02 & 14.10 & 4.04 & 7.41 & 1.54 & 27.51 & 8.16 \\
\hline UR & $0.35^{\mathrm{a}}$ & 0.10 & 0.68 & 0.15 & $0.56^{\mathrm{b}}$ & 0.17 & 1.44 & 0.32 \\
\hline $\mathrm{DH}$ & $19.35^{\mathrm{a}}$ & 2.41 & 66.94 & 15.24 & $35.57^{\mathrm{b}}$ & 1.86 & 80.43 & 24.43 \\
\hline $\mathrm{Cd}$ & 1.38 & 0.43 & 4.30 & 0.86 & 1.36 & 0.38 & 4.17 & 0.89 \\
\hline $\mathrm{Cu}$ & 14.35 & 3.69 & 63.78 & 14.29 & 15.50 & 2.34 & 74.04 & 16.22 \\
\hline $\mathrm{Ni}$ & 11.70 & 4.74 & 32.05 & 8.11 & 12.40 & 3.48 & 37.53 & 9.56 \\
\hline $\mathrm{Pb}$ & 83.60 & 28.15 & 234.55 & 54.64 & 66.96 & 16.00 & 269.80 & 53.62 \\
\hline $\mathrm{Zn}$ & 72.30 & 25.12 & 168.00 & 41.98 & 77.79 & 28.29 & 185.25 & 45.61 \\
\hline Acy & $0.0002^{\mathrm{a}}$ & 0.0001 & 0.0010 & 0.0004 & $0.0009^{\mathrm{b}}$ & 0.0001 & 0.0020 & 0.0006 \\
\hline Phe & 0.0055 & 0.0004 & 0.0115 & 0.0031 & 0.0061 & 0.0031 & 0.0127 & 0.0030 \\
\hline Flt & $0.0081^{\mathrm{a}}$ & 0.0001 & 0.0247 & 0.0092 & $0.0222^{b}$ & 0.0092 & 0.0533 & 0.0140 \\
\hline Pyr & $0.0073^{\mathrm{a}}$ & 0.0001 & 0.0235 & 0.0086 & $0.0203^{b}$ & 0.0074 & 0.0488 & 0.0127 \\
\hline $\mathrm{BaA}$ & $0.0035^{\mathrm{a}}$ & 0.0001 & 0.0146 & 0.0053 & $0.0088^{\mathrm{b}}$ & 0.0033 & 0.0217 & 0.0059 \\
\hline $\mathrm{Chr}$ & $0.0068^{\mathrm{a}}$ & 0.0001 & 0.0246 & 0.0100 & $0.0193^{b}$ & 0.0073 & 0.0444 & 0.0115 \\
\hline $\mathrm{BbF}$ & 0.0161 & 0.0017 & 0.0233 & 0.0062 & 0.0168 & 0.0055 & 0.0307 & 0.0084 \\
\hline $\mathrm{BkF}$ & 0.0034 & 0.0001 & 0.0076 & 0.0034 & 0.0058 & 0.0019 & 0.0126 & 0.0036 \\
\hline $\mathrm{BaP}$ & 0.0054 & 0.0001 & 0.0117 & 0.0053 & 0.0098 & 0.0032 & 0.0218 & 0.0056 \\
\hline DahA & 0.0001 & 0.0001 & 0.0001 & 0.0001 & 0.0003 & 0.0001 & 0.0023 & 0.0008 \\
\hline BghiP & $0.0025^{\mathrm{a}}$ & 0.0001 & 0.0092 & 0.0033 & $0.0047^{b}$ & 0.0001 & 0.0120 & 0.0036 \\
\hline IcdP & $0.0035^{\mathrm{a}}$ & 0.0001 & 0.0099 & 0.0036 & $0.0065^{b}$ & 0.0013 & 0.0132 & 0.0042 \\
\hline$\chi$ & 113.28 & 48.60 & 270.60 & 53.90 & 84.60 & 19.10 & 181.00 & 46.01 \\
\hline$\chi \mathrm{fd}$ & 1.38 & 0.36 & 3.07 & 0.59 & 1.55 & 0.16 & 4.00 & 0.88 \\
\hline
\end{tabular}

Different small letters in the upper index of the mean values mean significant differences; dehydrogenase (DH) activity is in $\mu \mathrm{mol}$ of triphenyl formazan (TPF) $\mathrm{kg}^{-1} \mathrm{~h}^{-1}$; urease (UR) activity is in $\mathrm{mmol}$ of $\mathrm{NH}_{4}^{+}$ $\mathrm{kg}^{-1} \mathrm{~h}^{-1} ; \mathrm{C}$ and $\mathrm{N}$ are shown as \%; sand, silt and clay are shown as \%

$\mathrm{Ht}$, total acidity; $\mathrm{Ca}, \mathrm{Mg}, \mathrm{K}, \mathrm{Na}$ content in $\mathrm{cmol}_{\mathrm{c}} \mathrm{kg}^{-1}$; $\mathrm{BC}$, base cations; $\mathrm{Cd}, \mathrm{Cu}, \mathrm{Ni}, \mathrm{Pb}$ and $\mathrm{Zn}$ in $\mathrm{mg} \mathrm{kg}^{-1} ; \chi$, mass magnetic susceptibility; $\chi_{\mathrm{fd}}$, percentage frequency-dependence magnetic susceptibility; Acy, acenaphthylene; Phe, phenanthrene; Flt, fluoranthene; Pyr, pyrene; BaA, benzo(a)anthracene; Chr, chrysene; $\mathrm{BkF}$, benzo(k)fluoranthene; $\mathrm{BbF}$, benzo(b)fluoranthene; $\mathrm{BaP}$, benzo(a)pyrene; IcdP, indeno(1,2,3-c,d)pyren; DahA, dibenzo(a,h)anthracene; BghiP, benzo(g,h,i)perylene in $\mu \mathrm{g} \mathrm{g}^{-1}$ content of $\mathrm{Cd}$, $\mathrm{Ni}$ and $\mathrm{Zn}$, and the activity of dehydrogenases with the content of $\mathrm{Ni}$. The activity of the examined enzymes was positively correlated with silt and clay content, negatively with sand content. Urease activity correlated with carbon content (Table 2). Moreover, there was a statistically significant relation between urease activity and the content of selected aromatic hydrocarbons. Urease activity negatively correlated with the content of acenaphthylene (Acy) pyrene (Pyr), benzo(b)fluoranthene $(\mathrm{BBF})$ and benzo(a)pyrene $(\mathrm{BaP})$. 

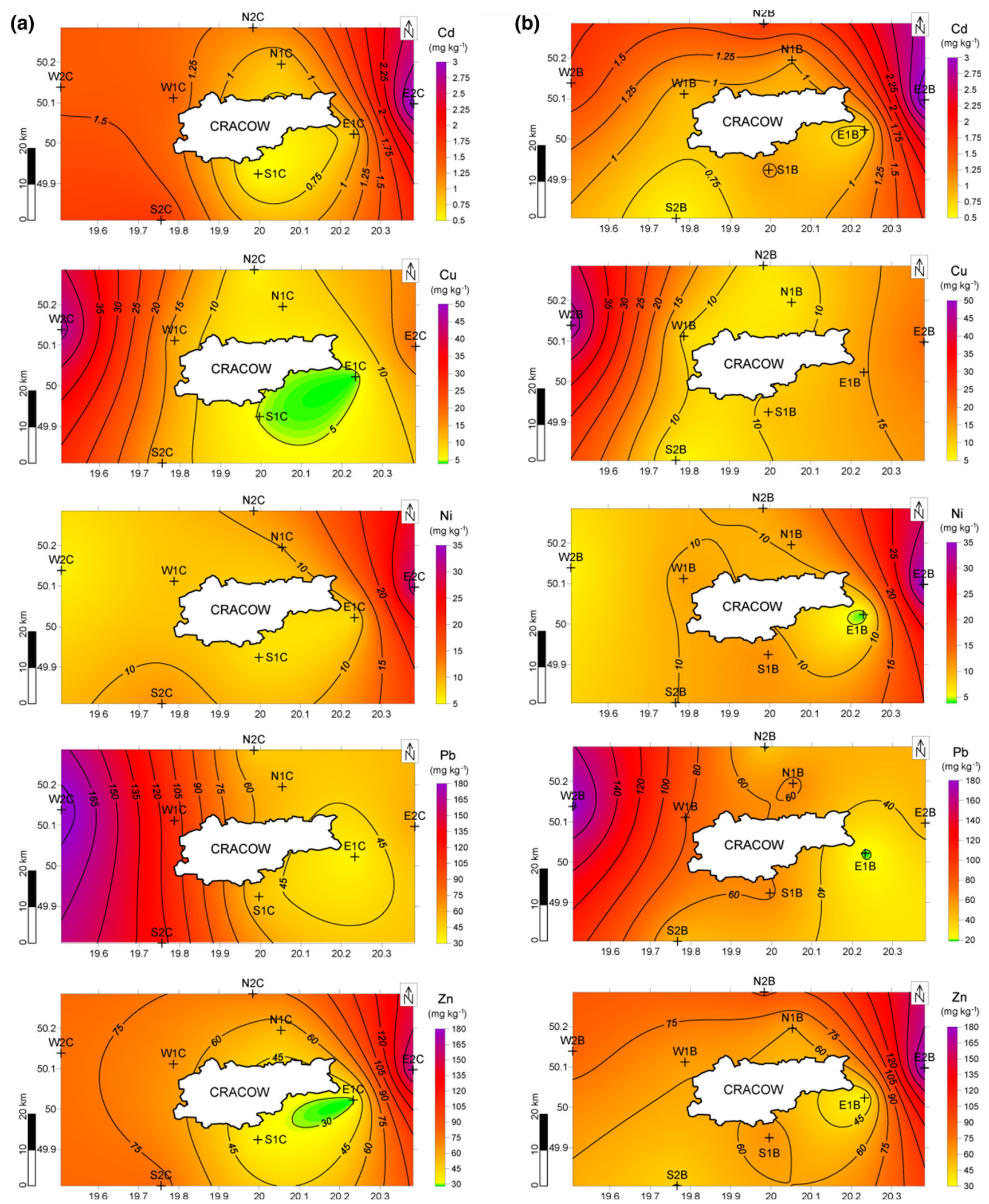

Fig. 2 Spatial distribution of mean contents of heavy metal $(\mathrm{Cd}, \mathrm{Cu}, \mathrm{Ni}, \mathrm{Pb}$ and $\mathrm{Zn}$ in soil taken under: a coniferous stands and $\mathbf{b}$ broadleaf stands around Krakow 

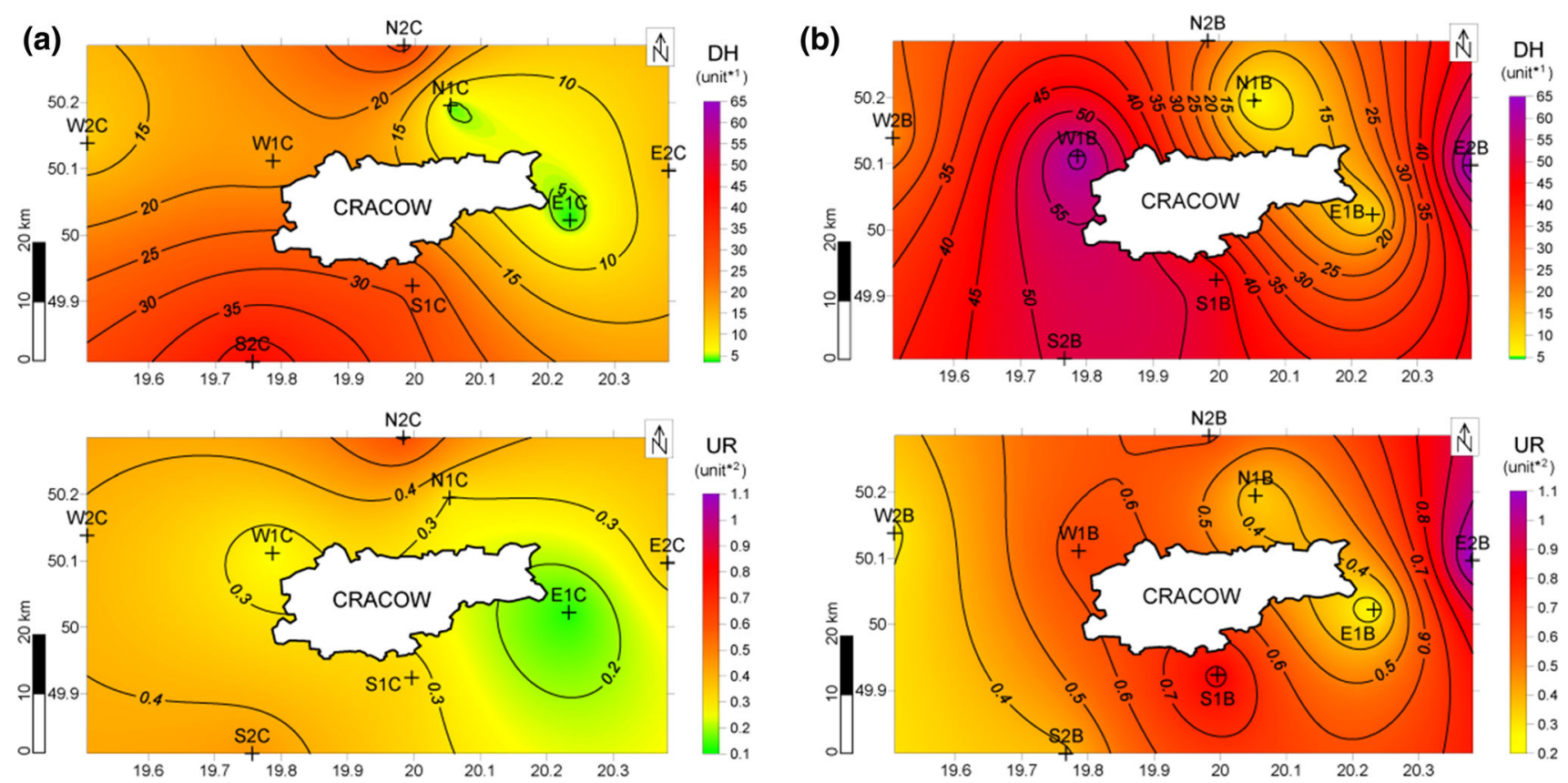

Fig. 3 Spatial distribution of mean soil enzyme activities (dehydrogenase (DH) activity is in $\mu$ mol of triphenyl formazan (TPF) $\mathrm{kg}^{-1} \mathrm{~h}^{-1}$; $\mathrm{urease}$ (UR) activity is in mmol of $\mathrm{NH}_{4}{ }^{+} \mathrm{kg}^{-1} \mathrm{~h}^{-1}$ ) in soil taken under: a coniferous stands and $\mathbf{b}$ broadleaf stands around Krakow

Table 2 Correlations between enzyme activities and soil characteristics in group of coniferous and broadleaf forest stands

\begin{tabular}{|c|c|c|c|c|c|c|c|c|c|c|c|c|c|c|}
\hline & $\mathrm{Cd}$ & $\mathrm{Cu}$ & $\mathrm{Ni}$ & $\mathrm{Pb}$ & $\mathrm{Zn}$ & $\mathrm{pHH}_{2} \mathrm{O}$ & Sand & Silt & Clay & $\mathrm{C}$ & $\mathrm{N}$ & $\mathrm{C} / \mathrm{N}$ & $\mathrm{BC}$ & $\chi$ \\
\hline \multicolumn{15}{|c|}{ Broadleaf stand } \\
\hline UR & $0.66^{*}$ & -0.14 & $0.77 *$ & -0.21 & $0.68 *$ & 0.32 & $-0.56^{*}$ & $0.53 *$ & $0.66^{*}$ & $0.52 *$ & 0.24 & -0.35 & $0.73 *$ & 0.07 \\
\hline $\mathrm{DH}$ & 0.26 & -0.19 & $0.56^{*}$ & -0.11 & 0.39 & 0.02 & -0.29 & 0.25 & $0.46^{*}$ & 0.34 & 0.17 & -0.02 & 0.35 & -0.01 \\
\hline \multicolumn{15}{|c|}{ Coniferous stand } \\
\hline UR & 0.12 & 0.12 & 0.09 & 0.17 & 0.27 & $0.44 *$ & $-0.44 *$ & $0.42 *$ & 0.34 & 0.36 & 0.33 & 0.08 & 0.36 & -0.21 \\
\hline $\mathrm{DH}$ & -0.02 & -0.15 & -0.03 & 0.11 & 0.05 & 0.22 & 0.06 & -0.11 & 0.01 & 0.37 & $0.43 *$ & 0.38 & 0.08 & -0.07 \\
\hline
\end{tabular}

$* p<0.05$

UR, urease activity; DH, dehydrogenase activity; $\mathrm{C}$, carbon content; $\mathrm{N}$, nitrogen content; $\mathrm{BC}$, base cations; $\chi$, mass magnetic susceptibility

In the case of soils of coniferous stands, there was no correlation between enzymatic activity and the content of heavy metals (Table 2). Urease activity positively correlated with $\mathrm{pH}$, dust and clay content, and negatively with sand content. Urease activity correlated negatively with chrysene (Chr) and benzo(g,h,i)perylene (BghiP). Dehydrogenase activity correlated negatively with phenanthrene (Phe), benzo(a)anthracene (BaA), chrysene (Chr), benzo(k)fluoranthene $(\mathrm{BkF})$, benzo(b)fluoranthene $(\mathrm{BbF})$, benzo(a)pyrene $(\mathrm{BaP})$, indeno(1,2,3-c,d)pyrene (IcdP) and benzo(g,h,i)perylene (BghiP) (Table 3).

\section{Magnetic susceptibility and frequency-dependent magnetic susceptibility}

Mass magnetic susceptibility $(\chi)$ measurements unambiguously show an increment tendency in soil samples obtained under coniferous forest in comparison with the samples obtained under deciduous forest. The $\chi$ values measured under coniferous forest remained within the range of $48.6-270.6 \times 10^{-8} \mathrm{~m}^{3} \mathrm{~kg}^{-1}$, while under deciduous forest they were within the range of 19.1-181.0 $\times$ $10^{-8} \mathrm{~m}^{3} \mathrm{~kg}^{-1}$ (Table 1). This was also observed for individual sampling points located at particular directions and distances from Krakow (Fig. 4). The lowest $\chi$ value was measured under coniferous forest at the distance of $35 \mathrm{~km}$ to the north of Krakow. The highest $\chi$ values were measured under coniferous forest at points located $15 \mathrm{~km}$ west of Krakow and $35 \mathrm{~km}$ east of Krakow. At points located under deciduous forest, the highest $\chi$ values were measured $15 \mathrm{~km}$ north of Krakow and the lowest $15 \mathrm{~km}$ east of Krakow (Fig. 4).

Percentage values of frequency-dependent magnetic susceptibility $\left(\chi_{\mathrm{fd}} \%\right)$ were comparable under both 
Table 3 Correlations between enzyme activities and polycyclic aromatic hydrocarbons (PAHs) in group of coniferous and broadleaf forest stands

\begin{tabular}{|c|c|c|c|c|c|c|c|c|c|c|c|}
\hline & Acy & Phe & Flt & Pyr & $\mathrm{BaA}$ & $\mathrm{Chr}$ & $\mathrm{BbF}$ & $\mathrm{BaP}$ & DahA & BghiP & IcdP \\
\hline \multicolumn{12}{|c|}{ Broadleaf stand } \\
\hline UR & $-0.41 *$ & -0.26 & -0.33 & $-0.41 *$ & -0.35 & -0.38 & $-0.50 *$ & $-0.52^{*}$ & 0.32 & -0.21 & -0.39 \\
\hline $\mathrm{DH}$ & 0.01 & 0.21 & 0.14 & 0.11 & 0.12 & 0.05 & -0.08 & -0.09 & 0.19 & -0.31 & -0.01 \\
\hline \multicolumn{12}{|c|}{ Coniferous stand } \\
\hline UR & $-0.40^{*}$ & -0.16 & -0.13 & -0.12 & -0.38 & $-0.48 *$ & -0.29 & -0.21 & -0.14 & $-0.61 *$ & -0.23 \\
\hline $\mathrm{DH}$ & -0.37 & $-0.40^{*}$ & -0.30 & -0.27 & $-0.41^{*}$ & $-0.47^{*}$ & $-0.51 *$ & $-0.50 *$ & $-0.46^{*}$ & $-0.61 *$ & $-0.44 *$ \\
\hline
\end{tabular}

$* p<0.05$

UR, urease activity; DH, dehydrogenase activity; Acy, acenaphthylene; Phe, phenanthrene; Flt, fluoranthene; Pyr, pyrene; BaA, benzo(a)anthracene; Chr, chrysene; BkF, benzo(k)fluoranthene; BbF, benzo(b)fluoranthene; BaP, benzo(a)pyrene; IcdP, indeno(1,2,3-c,d)pyren; DahA, dibenzo(a,h)anthracene; BghiP, benzo(g,h,i)perylene
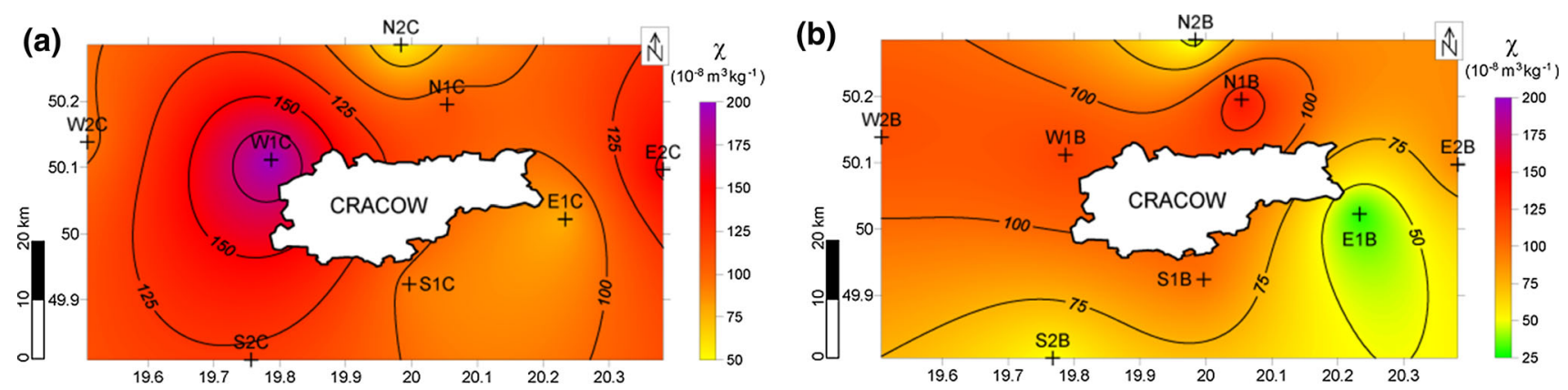

Fig. 4 Spatial distribution of mean values of mass magnetic susceptibility $(\chi)$ in soil taken under: a coniferous stands and $\mathbf{b}$ broadleaf stands around Krakow

deciduous and coniferous forests and did not exceed $4 \%$ (Table 1).

\section{Polycyclic aromatic hydrocarbons}

A higher average content of polycyclic aromatic hydrocarbons was observed in the soils of deciduous stands. The sum of PAHs in the soils of deciduous stands was $0.1215 \mu \mathrm{g} \mathrm{g}^{-1}$ and in the soils of coniferous stands $0.0623 \mu \mathrm{g} \mathrm{g}^{-1}$. Among the determined PAHs, the fluoranthene (Flt), pyrene (Pyr) and chrysene (Chr) were dominant in soil under deciduous stands. Benzo(b)fluoranthene $(\mathrm{BbF})$ was dominant in soils under coniferous stands (Table 1). The content of PAHs varied depending on the distance from Krakow. The highest sum of PAHs was observed in soils located $35 \mathrm{~km}$ to the south, $15 \mathrm{~km}$ to the east and $35 \mathrm{~km}$ to the west of Krakow $(0.1412,0.1143$, and $0.1032 \mu \mathrm{g} \mathrm{g}^{-1}$, respectively). The lowest content of aromatic hydrocarbons was recorded $35 \mathrm{~km}$ north of Krakow (Table 4).

Among the determined hydrocarbons, the most numerous ones found in the soils included: fluoranthene (Flt) (depending on the position, it is in the range 0.0019-0.0533 $\mathrm{g} \mathrm{g} \mathrm{g}^{-1}$ ), benzo(b)fluoranthene (BbF) (depending on the position, it is in the range 0.0016$0.0307 \mu \mathrm{g} \mathrm{g}^{-1}$ ), pyrene (Pyr) (depending on the position, the range varies from 0.0016 to $0.0488 \mu \mathrm{g} \mathrm{g}^{-1}$ ) and chrysene (Chr) (depending on the position, it is in the range $\left.0.0017-0.0444 \mu \mathrm{g} \mathrm{g}^{-1}\right)$. The least numerous ones found in the soils included: dibenzo(a,h)anthracene (DahA) (it was determined only in samples from deciduous stand $15 \mathrm{~km}$ to the south of Krakow) and acenaphthylene (Acy) (depending on the position, it is in the range 0.0001$0.0019 \mu \mathrm{g} \mathrm{g}^{-1}$ ) (Table 4). Differences in the PAH content depend on the number of benzene rings, as shown in Fig. 5. Four- and five-ring hydrocarbons were dominant in the studied soils. The soils $35 \mathrm{~km}$ south of Krakow and soils east of Krakow had the highest content of Flt, Pyr and Chr. In order to identify PAH sources, we used four diagnostic ratios. According to $\mathrm{LMW} / \mathrm{HMW}$ ratio, the investigated soils were affected by petrogenic sources (Table 4). IcdP/ $(\mathrm{IcdP}+\mathrm{BghiP})$, Flt/(Flt + Pyr $)$ and Flt/Pyr ratios indicated that soil around Krakow is influenced by coal/biomass burning (Table 4). 


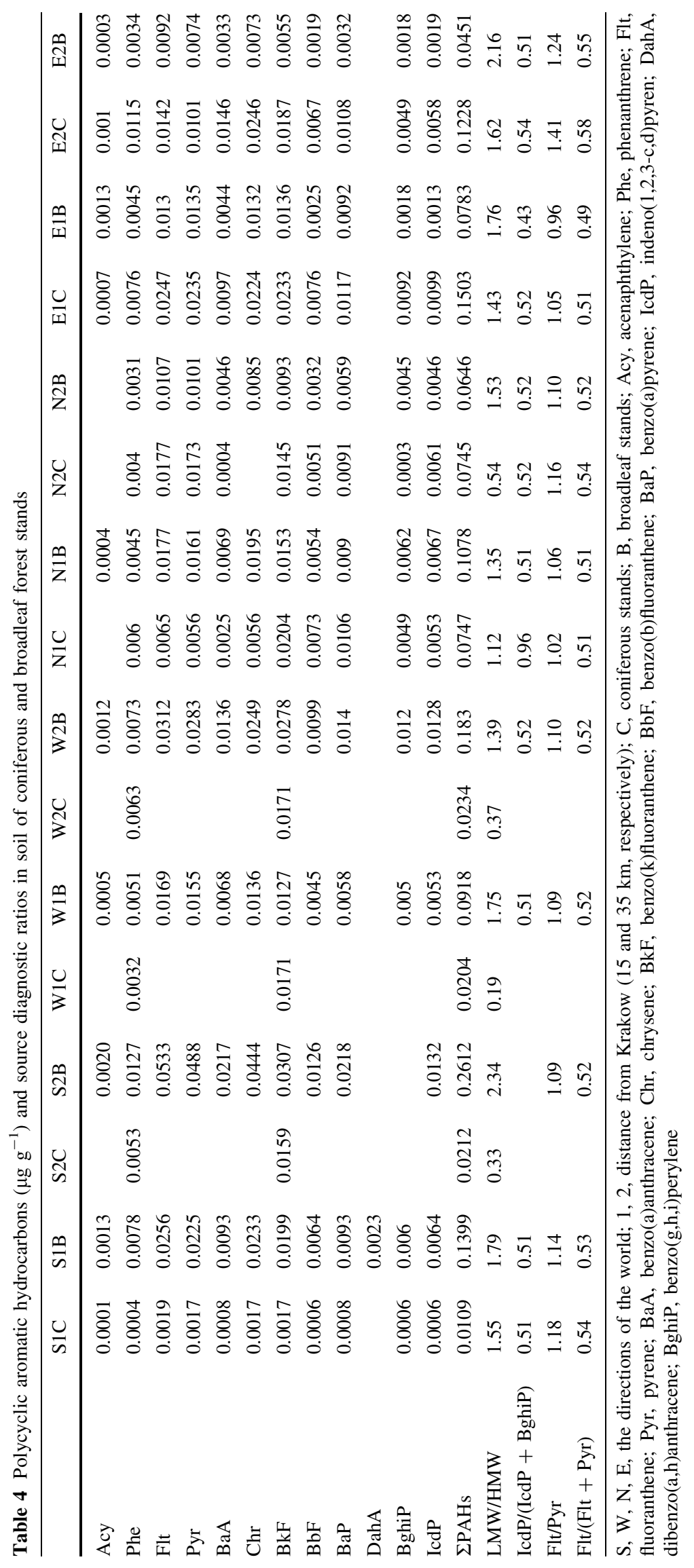




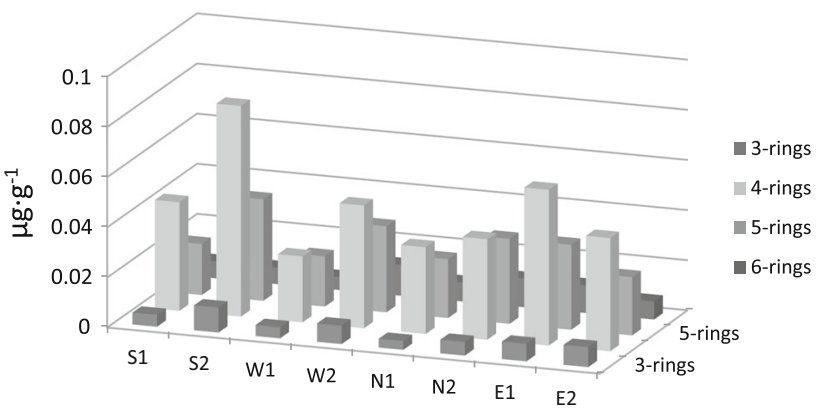

Fig. 5 PAHs content in soil depending on the benzene rings

\section{PCA analysis}

A projection of the variables on the factor-plane clearly demonstrated a correlation between the variables. Two main factors had a significant total impact $(50.78 \%)$ on the variance of the variables in the soil. Factor 1 explained $29.89 \%$ of the variance of the examined properties, and Factor 2 accounted for $20.89 \%$ of the variance (Fig. 6). The soil of deciduous stands had higher UR and DH activity, $\mathrm{pH}$ and the base cation content. The soils on research plots west of Krakow contained a lot of $\mathrm{Pb}, \mathrm{Cu}$ and were characterized by high magnetic susceptibility. Urease and dehydrogenase activities were associated with the $\mathrm{pH}$ and $\mathrm{BC}$ content (Fig. 6). The activity of the studied soil increased with the increase in $\mathrm{pH}$. Enzyme activity positively correlated with the nickel content. Heavy metals positively correlated with the carbon content (Fig. 6).

\section{Discussion}

The obtained results confirm the high diversity of forest soil pollution around Krakow agglomeration. Significant differences in both the content of heavy metals, polycyclic aromatic hydrocarbons and values of the magnetic susceptibility were observed in the soils of forest complexes located in different directions away from Krakow and at various distances from Krakow. The level of contamination is related to the historical and current deposition of industrial and urban dusts from Krakow and Silesia. As for the magnetic susceptibility and heavy metal content, the most divergent research plots were located west and east of Krakow. The level of soil pollution in those locations was affected by climatic conditions, i.e., the mainly western direction of the prevailing winds. Pollutants transferred from the Upper Silesian Industrial Region are deposited in the west while $35 \mathrm{~km}$ east of Krakow are deposited contaminants from Krakow, primarily from the steel producer ArcelorMittal Poland Unit in Krakow. According to Zhang et al. (2012), wind direction and speed might change the heavy metal contaminants of soil. Ogunkunle and Fatoba
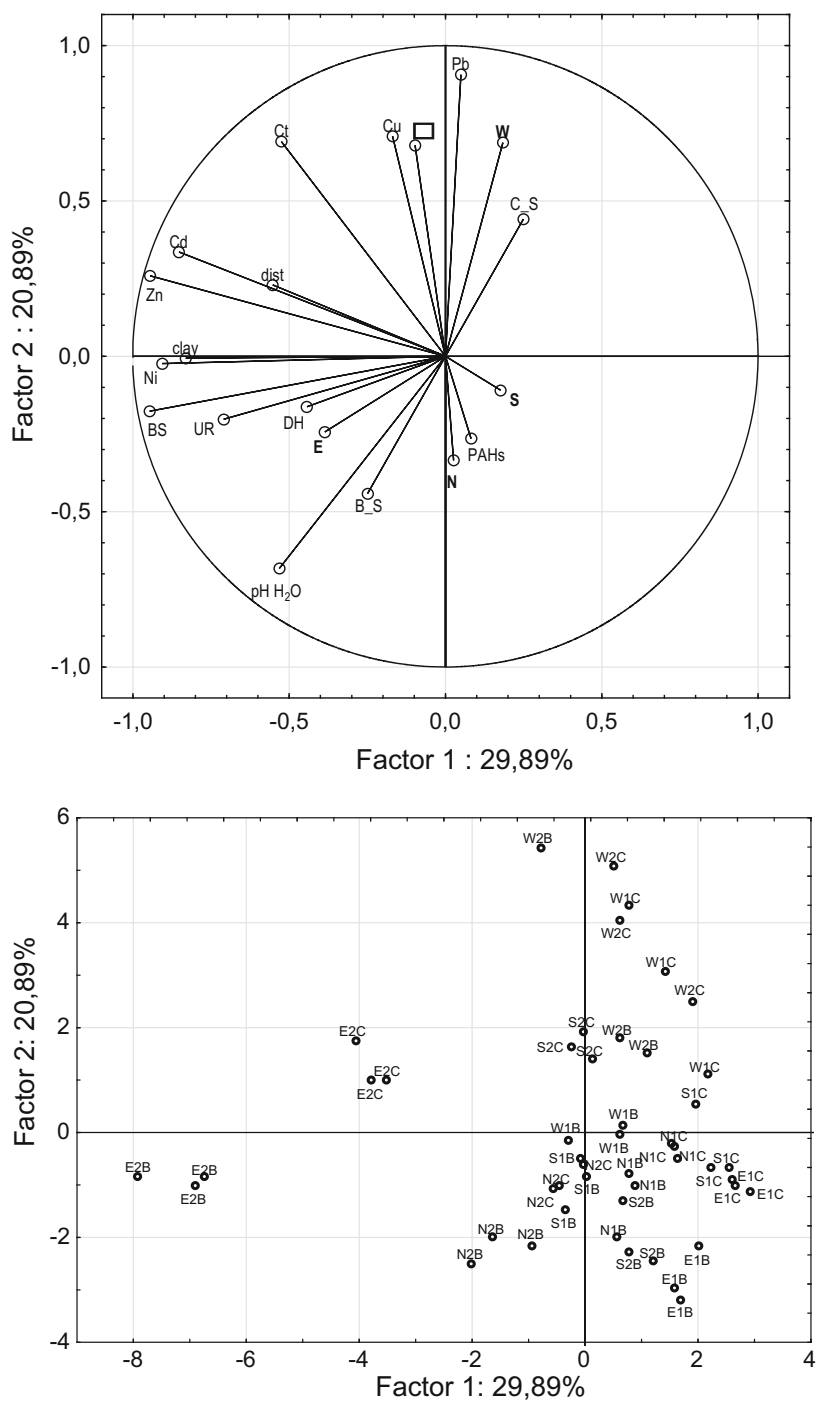

Fig. 6 Projection of the variables on the factor-plane in soil of coniferous and broadleaf stands together; $\mathrm{W}, \mathrm{E}, \mathrm{S}, \mathrm{N}$, the directions of the world; B_S, broadleaf stands; C_S, coniferous stands; UR, urease activity; DH, dehydrogenase activity; dist, distance from Krakow; $\chi$, mass magnetic susceptibility

(2014) studied the level of soil contamination by $\mathrm{Pb}, \mathrm{Cu}$, $\mathrm{Cr}, \mathrm{Cd}$ and $\mathrm{Zn}$ and showed that these heavy metals are deposited at various distances depending on wind velocity. Additionally, they indicated that the heavy metals which are found in the soil do not only come from cement production (second works of Lafarge-Cement WAPCO factory in Nigeria) but also from road traffic. According to Kabata-Pendias (2011), the admissible level of $\mathrm{Cd}$ amounts to $1 \mathrm{mg} \mathrm{kg}^{-1}$, $\mathrm{Cu}$ to $30 \mathrm{mg} \mathrm{kg}^{-1}$, Ni to $20 \mathrm{mg} \mathrm{kg}^{-1}, \mathrm{~Pb}$ to $50 \mathrm{mg} \mathrm{kg}^{-1}$ and $\mathrm{Zn}$ to $100 \mathrm{mg} \mathrm{kg}^{-1}$. The permissible content of heavy metals was exceeded most to the east and west of Krakow. The acceptable standards for cadmium are exceeded three times to the east and twice to the west of Krakow. The content of copper and lead exceeded the admissible level in deciduous and coniferous stands $35 \mathrm{~km}$ 
west of Krakow. The highest nickel content was determined $35 \mathrm{~km}$ to the east of Krakow in the soils of deciduous and coniferous stands (36.13 and $31.85 \mathrm{mg} \mathrm{kg}^{-1}$, respectively). The values reported there exceeded the admissible levels. The permissible content of zinc in soils was exceeded $35 \mathrm{~km}$ to the east of Krakow: The zinc content in the soils of coniferous stands was $166.98 \mathrm{mg} \mathrm{kg}^{-1}$, whereas in the soils of deciduous stands it amounted to $182.41 \mathrm{mg} \mathrm{kg}^{-1}$. The reported exceeded values are connected not only with industry but also with the impact of motorization. One of the main traffic routes in Poland, the Medyka-Zgorzelec motorway, runs east and west of Krakow. Moreover, west of Krakow there is Balice Airport. This Krakow Airport handles about four million passengers a year. Many studies have demonstrated the potential heavy metal pollution load of airfields, such as high $\mathrm{Pb}$ concentration in mosses and lichens in the Helsinki-Vantaa Airport area, Finland, elevated Pb concentration in the air at Heathrow Airport, London, UK, traffic emissions around the International Airport in Delhi, India (Nichols et al. 1981; Ray et al. 2012).

A high value of $\chi$ indicates significant concentration of ferrimagnetic minerals (Thompson et al. 1980). Magnetic susceptibility enhancement observed in topsoil samples suggests urban-industrial dust deposition as a source of TMPs in the studied area. Localization of the sampling sites in areas of significant emitters of air pollutants (i.e., the city of Krakow, the steel producer ArcelorMittal Poland Unit in Krakow, the "Eeg" power station and the Upper Silesian Industrial Region) as well as the prevailing wind direction revealed the spatial distribution of the observed magnetic susceptibility anomalies. These findings are in agreement with previous studies, e.g., by Łukasik et al. (2016), who reported that high $\chi$ values were found in mineral (A) horizons of the forest under the influence of Krakow's urban-industrial emissions due to the presence of the large steel producer (the steel producer ArcelorMittal Poland Unit in Krakow), located in Nowa Huta district. Moreover, many authors (e.g., Strzyszcz and Magiera 1998; Fürst et al. 2007; Blaha et al. 2008; Szuszkiewicz et al. 2016) reported that the highest contents of TMPs and accompanying heavy metals are observed in the topsoil organic (O) and mineral (A) horizons. According to previous findings (e.g., Zawadzki et al. 2009; Fürst et al. 2010), magnetic susceptibility is a suitable method for prediction of the spatial extent of heavy metal pollution in fly ash impacting forest areas.

The $\chi_{\mathrm{fd}}$ reflects the occurrence of ultra-fine superparamagnetic particles in the material (Dearing et al. 1996b); it has been applied to measure pedogenic and/or biogenic magnetic enhancement $\left(\chi_{\mathrm{fd}}>5 \%\right)$-cf. Dearing et al. (1996a). The values of $\chi_{\mathrm{fd}}<5 \%$ suggest a natural or anthropogenic source of magnetic particles. However, the surroundings of the study area (an urban-industrial setting) lead to a conclusion that $\chi_{\mathrm{fd}} \leq 4 \%$ measured in the examined soil samples is a result of the presence of TMPs.

The highest content of polycyclic aromatic hydrocarbons was observed to the east and south of Krakow. The most important sources of PAHs around Krakow are low emissions whose sources are coal combustion in individual home furnaces and traffic emissions. Additionally, industrial emissions (heavy industry, cogeneration plants) are PAH sources. For identifications of PAH sources, we used diagnostic ratios. Petrogenic sources and coal/biomass burning were identified. In Krakow surroundings, a lot of houses are heated using hard coal. The investigated soils are influenced by the emission from industrial activities in Krakow and Upper Silesian Industrial Region. The obtained values of diagnostic ratios suggest that the sources of PAHs could be not only industrial facilities but also vehicles. PAHs may be formed during incomplete combustion of organic materials including coal and wood. PAHs get into soils predominantly from dusts and rainfall; part of the dust becomes deposited on the aboveground parts of plants and gets into the soil after their death (Maliszewska-Kordybach 1999). Xiao et al. (2014) noted that traffic emissions and coal burning were the primary contributors to forest soil PAHs in the Pearl River Delta. Kwon and Choi (2014) indicated that diesel vehicle emission is a major source of PAHs. In addition, industrial emission sources, such as heavy oil combustion, coke ovens and coal burning, were identified. The type of stand had a considerable influence on the content of polycyclic aromatic hydrocarbons and the level of magnetic susceptibility. A higher content of aromatic hydrocarbons was observed in the soils of deciduous stands located to the east, north and south of Krakow. In soil situated east of Krakow, the higher content of PAHs was noted under coniferous stands. Physiological features of leaves play an important role in determination of the scavenging efficiency and retention of airborne particles on leaf surfaces (Howsam et al. 2000). The average scavenging efficiency was defined as the ratio of the number of particles deposited on the tree to the dose corresponding to the tree (Hidy 1973). Howsam et al. (2000) noted that leaves with hairs (oak, hazel) had a higher sum of PAH concentrations than those with recessed hairs. The role of other leaf components, such as lipids and epicuticular waxes, in leaf accumulation of PAHs, which are lipophilic compounds, was highlighted. Differences between the content of PAHs in the soil of coniferous stands and the soil of deciduous stands may be related to the surface area of leaves and needles. The annual litterfall in deciduous stands increases the deposition fluxes of aromatic hydrocarbons. In addition, 
according to Terytze et al. (1995), PAHs are characterized by a strong sorption affinity with respect to the soil organic matter. Yang et al. (2014) suggest that pine needle litterderived dissolved organic matter (DOM) can have a substantial effect of inhibiting PAH sorption and promoting PAH desorption, thus leading to enhanced leaching in soil, which should be taken into account in risk assessment of PAHs accumulated in forest soil.

The applied biochemical parameters, i.e., the enzymatic activity, correlated negatively with the content of selected polycyclic aromatic hydrocarbons and their sum. Polycyclic aromatic hydrocarbons can inhibit the development and metabolic activity of microorganisms (Baran et al. 2004). In the present study, a negative correlation was noted between urease and dehydrogenase, and the selected aromatic hydrocarbons. Urease activity correlated with the contents of Acy, Pyr, BbF, BaP, Chr and BghiP, while dehydrogenase activity correlated mainly with four-, fiveand six-ring hydrocarbons (Phe, BaA, Chr, BbF, BaP, DahA, BghiP and IcdP). According to Thavamani et al. (2012), PAHs in long-term contaminated soils could have a strong and complex impact on microbial community structure activities. It may be concluded that the differences in enzymatic activity between the research plots result from different contents of PAHs and different amount of soil organic matter as a result of species composition. The chemical composition of SOM largely results from microbial transformation of tree litter, whose composition, in turn, influences the activity and diversity of soil microorganisms (Pérez-Bejarano et al. 2010; Ushio et al. 2008). Deciduous species had a positive impact on soil organic matter and the most beneficial impact on the intensification of microbial activity. At the same time, a weaker relation was noted between enzymatic activity and heavy metal content. The inhibition of urease and dehydrogenase activity as a result of heavy metal pollution has been reported by many scientists (Chen et al. 2005; Shen et al. 2005; Sardar et al. 2010). The sequence of inhibition of urease activity was generally in the decreasing order of $\mathrm{Cr}>\mathrm{Cd}>\mathrm{Cu}>\mathrm{Zn}>\mathrm{Mn}>\mathrm{Pb}$. However, the stimulating effects of heavy metals have also been documented (Bååth 1989; Błońska et al. 2015). In the present study, a positive correlation was noted between urease activity and the content of $\mathrm{Cd}, \mathrm{Ni}$ and $\mathrm{Zn}$ as well as between dehydrogenase activity and the content of Ni. Metals detected in small amounts in the soil are not harmful and can even stimulate certain enzyme processes. It may be the case that a metal could be one of the components of the catalytic center and may activate selected enzymes by creating a metal-substrate complex (Balicka and Varanka 1978). The described relationships concerned the soils of deciduous stands.

\section{Conclusions}

Significant differences in the content of heavy metals, polycyclic aromatic hydrocarbons and values of magnetic susceptibility were observed in the soils of forest complexes located in different directions away from Krakow and at various distances from Krakow. As for the soil contamination, the most divergent research plots were located west and east of Krakow. The level of contamination is related to the historical and current deposition of industrial and urban dusts from Krakow and Silesia. The type of stand had a considerable influence on the content of polycyclic aromatic hydrocarbons. A higher content of aromatic hydrocarbons was observed in the soils of deciduous stands. Enhanced values of magnetic susceptibility and low values of frequency-dependence magnetic susceptibility indicate presence of TMPs in topsoil horizons of studied soils. The observation encompasses the results obtained under coniferous and broadleaf forest. The differences in enzymatic activity between the research plots result from different contents of PAHs and different amount of soil organic matter as a result of species composition. The stimulating effects of heavy metals on biochemical properties were noted. In the present study, a positive correlation was noted between urease activity and the content of $\mathrm{Cd}$, $\mathrm{Ni}$ and $\mathrm{Zn}$ as well as between dehydrogenase activity and the content of $\mathrm{Ni}$.

Acknowledgments This research was financed by the Ministry of Science and Higher Education of the Republic of Poland.

Open Access This article is distributed under the terms of the Creative Commons Attribution 4.0 International License (http://crea tivecommons.org/licenses/by/4.0/), which permits unrestricted use, distribution, and reproduction in any medium, provided you give appropriate credit to the original author(s) and the source, provide a link to the Creative Commons license, and indicate if changes were made.

\section{References}

Agrawal P, Mittal A, Prakash R, Kumar M, Singh TB, Tripathi SK (2010) Assessment of contamination of soil due to heavy metals around coal fired thermal power plants at Singrauli Region of India. Bull Environ Contam Toxicol 85:219-223

Alef K, Nannipieri P (1995) Enzyme activities. In: Alef K, Nannipieri $\mathrm{P}$ (eds) Methods in applied soil microbiology and biochemistry. Academic Press, London

Augusto L, Ranger J, Binkley D, Rothe A (2002) Impact of several common tree species of European temperate forests on soil fertility. Ann For Sci 59:233-253

Bååth E (1989) Effects of heavy metals in soil on microbial processes and populations (a review). Water Air Soil Pollut 47:335-379

Balicka N, Varanka MW (1978) Effect of industrial pollution of air on soil microflora. Zeszyty Problemowe Postępów Nauk Rolniczych 206:17-27 
Baran S, Bielińska JE, Oleszczuk P (2004) Enzymatic activity in an air field soil polluted with polycyclic aromatic hydrocarbons. Geoderma 118:221-232

Baumard P, Budzinski H, Garrigues P, Dizer H, Hansen PD (1999) Polycyclic aromatic hydrocarbons in recent sediments and mussels (Mytilus edulis) from the Western Baltic Sea: occurrence, bioavailability and seasonal variations. Mar Environ Res 47(1):17-47

Biernacka E, Małuszyńska MJ (2006) The content of cadmium, lead and selenium in soils from selected sites in Poland. Pol J Environ Stud 15(2a):7-9

Blaha U, Appel E, Stanjek H (2008) Determination of anthropogenic boundary depth in industrially polluted soil and semi-quantification of heavy metal loads using magnetic susceptibility. Environ Pollut 156:278-289

Błońska E, Januszek K (2013) Usability of enzyme activity in estimation of forest soil quality. Folia For Pol Ser A For 55(1):18-26

Błońska E, Małek S, Januszek K, Barszcz J, Wanic T (2015) Changes in forest soil properties and in spruce stands after dolomite, magnesite and serpentinite fertilization. Eur J Forest Res 134:981-990

Borůvka L, Drábek O (2004) Heavy metal distribution between fraction of humic substances in heavily polluted soils. Plant Soil Environ 50(8):339-345

Buurman P, van Lagen B, Velthorst EJ (1996) Manual for soil and water analysis. Backhuys Publishers, Leiden

Chaparro MAE, Gogorza CSG, Chaparro MAE, Irurzun MA, Sinito AM (2006) Review of magnetism and pollution studies of various environments in Argentina. Earth Planets Space 58(10):1411-1422

Chen CL, Lio M, Huang CY (2005) Effect of combined pollution by heavy metals on soil enzymatic activities in areas polluted by tailing from $\mathrm{Pb}-\mathrm{Zn}-\mathrm{Ag}$ mine. J Environ Sci 17:637-640

Chodak M, Gołębiewski M, Morawska-Płoskonka J, Kuduk K, Niklińska M (2013) Diversity of microorganisms from forest soils differently polluted with heavy metals. Appl Soil Ecol 64:7-14

Dearing JA, Dann RJL, Hay K, Lees JA, Loveland PJ, Maher BA, O'Grady K (1996a) Frequency-dependent susceptibility measurements of environmental materials. Geophys J Int 124:228 240

Dearing JA, Hay K, Baban S, Huddleston A, Wellington E, Loveland P (1996b) Magnetic susceptibility of soils: a test of conflicting theories using a national database. Geophys J Int 127:728-734

Friedlová M (2010) The influence of heavy metals on soil biological and chemical properties. Soil Water Res 5(1):21-27

Fürst C, Lorz C, Makeschin F (2007) Development of forest ecosystems after heavy deposition loads considering Dübener heide as example-challenges for a process-oriented forest management planning. For Ecol Manag 248:6-16

Fürst Ch, Lorz C, Zirlewagen D, Makeschin F (2010) Testing the indicative value of magnetic susceptibility measurements for concluding on site potentials and risk provoked by fly ash deposition. Environ Manag 46:894-907

Gałka B, Kabała C, Łabaz B, Bogacz A (2014) Influence of stands with diversed share of Norway spruce in species structure on soils of various forest habitats in the Stołowe Mountains. Sylwan 158(9):684-694

Gruba P, Mulder J (2015) Tree species affect cation exchange capacity (CEC) and cation binding properties of organic matter in acid forest soils. Sci Total Environ 511:655-662

Heller F, Strzyszcz Z, Magiera T (1998) Magnetic record of industrial pollution in forest soils of Upper Silesia, Poland. J Geophys Res 103(B8):17767-17774
Hidy GM (1973) Removal processes of gaseous and particulate pollutants. In: Rasool S (ed) Chemistry of the lower atmosphere. Plenum Press, New York, pp 127-176

Hobbie SE, Ogdahl M, Chorover J, Chadwick OA, Oleksyn J, Zytkowiak R, Reich PB (2007) Tree Species effects on soil organic matter dynamics: the role of soil cation composition. Ecosystems 10:999-1018

Howsam M, Jones KC, Ineson P (2000) PAHs associated with the leaves of three deciduous tree species. I. Concentrations and profiles. Environ Pollut 108:413-424

Hulett LD, Weinberger AJ, Northcutt KJ, Ferguson M (1980) Chemical species in fly ash from coal-burning power plant. Science 210:1356-1358

IUSS Working Group WRB (2006) World Reference Base for Soil Resources. World Soil Resources Reports 103. FAO, Rome, p 128

Kabata-Pendias A (2011) Trace elements in soils and plants, 4th edn. Taylor and Francis, New York

Klamerus-Iwan A, Błońska E, Lasota J, Kalandyk A, Waligórski P (2015) Influence of oil contamination on physical and biological properties of forest soil after chainsaw use. Water Air Soil Pollut 226:389

Komprdová K, Komprda J, Menšik L, Vaňková L, Kulhavý J, Nizzetto 1 (2016) The influence of tree species composition on the storage and mobility of semivolatile organic compounds in forest soils. Sci Total Environ 29(553):532-540

Kumar S, Chaudhuri S, Maiti SK (2013) Soil dehydrogenase enzymes activity in natural and mine soil-a review. Middle East J Sci Res 13(7):898-906

Kwon HO, Choi SD (2014) Polycyclic aromatic hydrocarbons (PAHs) in soils from a multi-industrial city South Korea. Sci Total Environ 470-471:1494-1501

Larsen RK, Baker JE (2003) Source apportionment of polycyclic aromatic hydrocarbons in the urban atmosphere: a comparison of three methods. Environ Sci Technol 37:1873-1881

Lipińska A, Kucharski J, Wyszkowska J (2014) Activity of arylsulphatase in soil contaminated with polycyclic aromatic hydrocarbons. Water Air Soil Pollut 225:2097

Łukasik A, Magiera T, Lasota J, Błońska E (2016) Background value of magnetic susceptibility in forest topsoil: assessment on the basis of studies conducted in forest research of Poland. Geoderma 264:140-149

Magiera T, Strzyszcz Z, Rachwal M (2007) Mapping particulate pollution loads using soil magnetometry in urban forests in the Upper Silesia Industrial Region, Poland. For Ecol Manag 248(1):36-42

Magiera T, Jabłońska M, Strzyszcz Z, Rachwał M (2011) Morphological and mineralogical forms of technogenic magnetic particles in industrial dusts. Atmos Environ 45:4281-4290

Maliszewska-Kordybach B (1999) Persistent organic contaminants in the environment: PAHs as a case study. In: Block JC, Goncharuk VV, Baveye Ph (eds) Bioavailability of organic xenobiotics in the environment., NATO ASI seriesKluwer, Dordrecht, pp 3-34

Maliszewska-Kordybach B, Smreczek B, Klimokowicz-Pawlas A, Terelak H (2008) Monitoring of the total content of polycyclic aromatic hydrocarbons (PAHs) in arable soils in Poland. Chemosphere 73(8):1284-1291

Matuszko D (2007) The climate of Krakow in XX century. IGiGP UJ, Kraków, pp 1-260 (in Polish)

Mueller KE, Eissenstat DM, Hobbie SE, Oleksyn J, Jagodziński AM, Reich PB, Chadwick OA, Chorover J (2012) Tree species effects on coupled cycles of carbon, nitrogen, and acidity in mineral soils at a common garden experiment. Biogeochemistry 111:601-614 
Nichols TP, Leinster P, McIntyre AE, Lester JN, Perry R (1981) A survey of air pollution in the vicinity of Heathrow airport (London). Sci Total Environ 19(3):285-292

Ogunkunle CO, Fatoba PO (2014) Contamination and spatial distribution of heavy metals in topsoil surrounding a mega cement factor. Atmos Pollut Res 5(2):270-282

Ostrowska A, Gawlinski S, Szczubiałka Z (1991) Methods of analysis and assessment of soil and plant properties. Environmental Protection Institute, Warszawa (in Polish)

Pérez-Bejarano A, Mataix-Solera J, Zornoza R, Guerrero C, Arcenegui V, Mataix-Beneyto J, Cano-Amat S (2010) Influence of plant species on physical, chemical and biological soil properties in a Mediterranean forest soil. Eur J Forest Res 129:15-24

Petrovský E, Kapička A, Jordanova N, Knab M, Hoffmann V (2000) Low-field magnetic susceptibility: a proxy method of estimating increased pollution of different environmental systems. Environ Geol 39:312-318

Ray S, Khillare PS, Kim KH (2012) The effect of aircraft traffic emissions on the soil surface contamination analysis around the international airport in Delhi, India. Asian J Atmos Environ 6-2:118-126

Reeves WR, Mc Donald TJ, Cizmas L, Donelly KC (2004) Portioning and desorption behavior of polycyclic aromatic hydrocarbons from disparate sources. Sci Total Environ 332:183-192

Sardar K, Abol El-Latif H, Min Q, Shafigur R, Ji-zheng H (2010) Effect of $\mathrm{Cd}$ and $\mathrm{Pb}$ on soil microbial community structure and ctivities. Environ Sci Pollut Res 17:288-296

Shen G, Lu Y, Zhou Q, Hong J (2005) Interaction of polycyclic aromatic hydrocarbons and heavy metals on soil enzyme. Chemosphere 61:1175-1182

Šmejkalová M, Mikanová O, Borůvka L (2003) Effects of heavy metal concentrations on biological activity of soil microorganisms. Plant Soil Environ 49(7):321-326

Soclo HH, Garrigues P, Ewald M (2000) Origin of polycyclic aromatic hydrocarbons (PAHs) in coastal marine sediments case studies in Cotonou (Benin) and Aquitaine (France) areas. Mar Pollut Bull 40:387-396

Srogi K (2007) Monitoring of environmental exposure to polycyclic aromatic hydrocarbons: a review. Environ Chem Lett 5:169-195

Strzyszcz Z, Magiera T (1998) Heavy metal contamination and magnetic susceptibility in soils of southern Poland. Phys Chem Earth 23(9-10):1127-1131

Szuszkiewicz M, Łukasik A, Magiera T, Mendakiewicz M (2016) Combination of geo-pedo- and technogenic magnetic and geochemical signals in soil profiles-diversification and its interpretation: a new approach. Environ Pollut 214:464-477

Tabatabai MA, Bremner JM (1972) Assay of urease activity in soils. Soil Biol Biochem 4:479-487
Terytze K, Kördel W, Aldag R, Hanel J, Hein D, Keller E, Klein M, Kuhnt G, Müller-Wegener U, Scheunert I, Schmidt M, Spiteller M, Von der Trenck KT (1995) Detection and determination limits of priority organic pollutants in soil. Chemosphere 31(4):3051-3083

Thavamani P, Malik S, Beer M, Megharaj M, Naidu R (2012) Microbial activity and diversity in long-term mixed contaminated soils with respect to polyaromatic hydrocarbons and heavy metals. J Environ Manag 99:10-17

Thompson R, Bloemendal J, Dearing JA, Oldfield F, Rummery TA, Stober JC, Turner GM (1980) Environmental application of magnetic measurements. Science 207:481-486

Ushio M, Wagai R, Balser TC, Kitayama K (2008) Variations in the soil microbial community composition of a tropical montane forest ecosystem: does tree species matter? Soil Biol Biochem 40:2699-2702

Wang YP, Shi JI, Wang H, Lin Q, Chen XC, Chen YX (2007) The influence of soil heavy metals pollution on soil microbial biomass, enzyme activity, and community composition near a copper smelter. Ecotoxicol Environ Saf 67:75-81

Wang X-T, Miao Y, Zhang Y, Li Y-C, Wu M-H, Yu G (2013) Polycyclic aromatic hydrocarbons (PAHs) in urban soils of the megacity Shanghai: occurence, source apportionment and potential human health risk. Sci Total Environ 447:80-89

Xia D, Wang B, Yu Y, Jia J, Nie Y, Wang X, Xu S (2014) Combination of magnetic parameters and heavy metals to discriminate soil-contamination sources in Yinchuan-a typical oasis city of Northwestern China. Sci Total Environ 485-486: 83-92

Xiao Y, Tong F, Kuang Y, Chen B (2014) Distribution and source apportionment of polycyclic aromatic hydrocarbons (PAHs) in forest soil from urban to rural areas in the Pearl River Delta of southern China. Int J Environ Res Public Health 11:2642-2656

Yang XH, Garnier P, Wang SZ, Bergheaud V, Huang XF, Qiu RL (2014) PAHs sorption and desorption on soil influenced by pine needle litter derived dissolved organic matter. Pedosphere 24(5): $575-584$

Yunker MB, Macdonald RW, Vingarzan R, Mitchell RM, Goyette D, Sylvestre S (2002) PAHs in the Fraser River basin: a critical appraisal of $\mathrm{PAH}$ ratios as indicators of PAH source and composition. Org Geochem 33:489-515

Zawadzki J, Magiera T, Fabijańczyk P (2009) Geostatistical evaluation of magnetic indicators of forest soil contamination with heavy metals. Stud Geophys Geod 53:133-149

Zhang F, Yan X, Zeng C, Zhang M, Shrestha S, Derkota LP, Yao T (2012) Influence of traffic activity on heavy metal concentrations of roadside farmland soil in mountains areas. Int $\mathrm{J}$ Environ Res Public Health 9:1715-1731 